\title{
OCCURRENCE AND STRUCTURE OF ARBUSCULAR MYCORRHIZAL FUNGAL COMMUNITIES IN CASSAVA AFTER CULTIVATION OF COVER CROPS AS OBSERVED BY THE "PCR-DGGE" TECHNIQUE
}

\author{
Elaine dos Santos Heberle ${ }^{(1)^{*}}$, Rafael Dutra de Armas ${ }^{(2)}$, Daniel Alexandre Heberle ${ }^{(3)}$, Sidney \\ Luiz Stürmer ${ }^{(4)}$, Luiz Augusto Martins Peruch(5), Paulo Emílio Lovato ${ }^{(6)}$ and Cláudio Roberto \\ Fonsêca Sousa Soares $^{(7)}$
}

(1) Universidade Federal de Santa Catarina, Campus Universitário Reitor David Ferreira Lima, Programa de Pós-Graduação em Agroecossistemas, Florianópolis, Santa Catarina, Brasil.

(2) Universidade Federal de Santa Catarina, Campus Universitário Reitor David Ferreira Lima, Programa de Pós-Graduação em Biotecnologia e Biociências, Florianópolis, Santa Catarina, Brasil.

(3) Universidade do Estado de Santa Catarina, Programa de Pós-Graduação em Ciência do Solo, Lages, Santa Catarina, Brasil.

(4) Universidade Regional de Blumenau, Departamento de Ciências Naturais, Blumenau, Santa Catarina, Brasil.

(5) Empresa de Pesquisa Agropecuária e Extensão Rural de Santa Catarina, Estação Experimental de Urussanga, Urussanga, Santa Catarina, Brasil.

${ }^{(6)}$ Universidade Federal de Santa Catarina, Campus Universitário Reitor David Ferreira Lima, Departamento de Engenharia Rural, Florianópolis, Santa Catarina, Brasil.

(7) Universidade Federal de Santa Catarina, Campus Universitário Reitor David Ferreira Lima, Departamento de Microbiologia, Imunologia e Parasitologia, Florianópolis, Santa Catarina, Brasil.

* Corresponding author.

E-mail: elainesantos82@yahoo.com.br

\begin{abstract}
Cassava (Manihot esculenta Crantz) is a highly mycotrophic crop, and prior soil cover may affect the density of arbuscular mycorrhizal fungi (AMFs), as well as the composition of the AMFs community in the soil. The aim of this study was to evaluate the occurrence and the structure of AMFs communities in cassava grown after different cover crops, and the effect of the cover crop on mineral nutrition and cassava yield under an organic farming system. The occurrence and structure of the AMFs community was evaluated through polymerase chain reaction (PCR) and denaturing gradient gel electrophoresis (DGGE). A randomized block
\end{abstract}


experimental design was used with four replications. Six different cover crop management systems before cassava were evaluated: black oats, vetch, oilseed radish, intercropped oats + vetch, intercropped oats + vetch + oilseed radish, plus a control (fallow) treatment mowed every 15 days. Oats as a single crop or oats intercropped with vetch or with oilseed radish increased AMFs inoculum potential in soil with a low number of propagules, thus benefiting mycorrhizal colonization of cassava root. The treatments did not affect the structure of AMFs communities in the soil since the AMFs communities were similar in cassava roots in succession to different cover crops. AMFs colonization was high despite high $P$ availability in the soil. The cassava crop yield was above the regional average, and $P$ levels in the leaves were adequate, regardless of which cover crop treatments were used. One cover crop cycle prior to the cassava crop was not enough to observe a significant response in variables, $P$ in plant tissue, crop yield, and occurrence and structure of AMFs communities in the soil. In the cassava roots in succession, the plant developmental stage affected the groupings of the structure of the AMF community.

Keywords: Manihot esculenta, arbuscular mycorrhizal fungi, root symbioses.

\section{RESUMO: COMUNIDADES DE FUNGOS MICORRÍZICOS ARBUSCULARES POR PCR-DGGE NA CULTURA DA MANDIOCA, APÓS CULTIVO DE PLANTAS DE COBERTURA}

A mandioca é uma planta altamente micotrófica, e o sistema de pré-cultivo pode influenciar a densidade de propágulos de fungos micorrízicos arbusculares (FMAs) e a composição de suas comunidades. $O$ objetivo deste trabalho foi avaliar a ocorrência e estrutura de comunidades de FMAs por reação em cadeia da polimerase (PCR) e eletroforese em gel de gradiente desnaturante (DGGE) na cultura da mandioca (Manihot esculenta Crantz), após cultivo de plantas de cobertura (PC), bem como a influência das comunidades de FMAs sobre a nutrição mineral e produção da mandioca em sistema de cultivo orgânico. Foram testados seis tratamentos de pré-cultivo de PC, incluindo: Aveia (A), Ervilhaca (E), Nabo (N), consórcio $A+E$ e consórcio $A+E+N$, além de um tratamento-controle com roçadas a cada 15 dias em delineamento em blocos casualizados com quatro repetições. O pré-cultivo com aveia e seu consórcio com ervilhaca e nabo favoreceram o potencial de inóculo de FMAs em solo com baixo número de propágulos, beneficiando a colonização micorrízica da mandioca. O pré-cultivo de plantas de cobertura não influenciou a estrutura de comunidades de FMAs no solo; no entanto, houve similaridade da comunidade de FMAs entre os tratamentos de PC nas raizes da mandioca em sucessão. Mesmo com alta disponibilidade de $P$ no solo, a colonização micorrízica da mandioca foi elevada e esses fatores contribuíram para os teores foliares de Pe o rendimento da cultura, independentemente das plantas de cobertura utilizadas. Um ciclo de cultivo das PC no cultivo da mandioca não foi suficiente para obter resposta significativa nas variáveis $P$ no tecido vegetal, rendimento da cultura, ocorrência e na estrutura de comunidades de FMAs no solo. Nas raizes da mandioca em sucessão, o estádio de desenvolvimento da planta interferiu nos agrupamentos da estrutura de comunidade de FMAs.

Palavras-chave: Manihot esculenta, micorrizas arbusculares, simbioses radiculares.

\section{INTRODUCTION}

Cassava (or manioc) (Manihot esculenta Crantz) is cultivated throughout Brazil because it can adapt to the variable soil and climate conditions of the country. This crop is closely associated with food security, as it is consumed in several different ways, and cassava products are obtained from the processing of its flour, or by consumption of its roots. In addition, all parts of the plant, such as leaves, stalks, and residue, can be used for animal feed, fertilizer, and pest control (Alves et al., 2009; IBGE, 2010).
Cassava is generally grown by small farmers, with low technological input in terms of nutrient intake. The constant use of cassava by these traditional communities may be influenced both by propagation and multiplication of the plant; propagation material (stem cuttings) is available for new planting after each crop, and the cassava plant is hardy and adapts to environmental variations (Alves, 2006).

The leaf structure of cassava is characterized by low biomass production, with limited soil surface coverage and low input of organic matter; these situations lead to soil loss (Souza and Souza, 2006). In addition, high plant spacing, commonly 
adopted for the crop, and leaf shedding during the dormancy period result in higher exposure of the soil to erosive agents (Carvalho and Fukuda, 2006). An alternative to minimize these problems is to use cover crops prior to planting cassava, the main purpose of which is to cover the soil, thus reducing erosion and incorporating organic matter, as well as to increase the fertility and microbial activity in the soil (Bettiol et al., 2002).

In addition to protecting the soil, cover crops play an important role in multiplying the propagules of arbuscular mycorrhizal fungi (AMFs) (Karasawa and Takebe, 2012). These microorganisms are obligate biotrophic fungi, and they contribute to the nutrition of various crops by increasing the absorption of nutrients that have low soil mobility, as is the case of P (Moreira and Siqueira, 2006). The diversity and the structure of AMFs communities present in the soil are influenced by symbiotic plants (Gomide et al., 2009), which may possibly exert selection pressure on $\mathrm{AMF}$, given the various biochemical mechanisms for recognition among the organisms involved, resulting in some degree of specificity for such symbiosis (Vandenkoornhuyse et al., 2003).

Cassava is highly mycotrophic and has high mycorrhizal dependency since cropped plants have a poorly developed root system in their early stages (Colozzi and Nogueira, 2007). Therefore, the multiplying property of cover crops is an alternative for increasing the inoculum potential of AMFs in the soil (Souza et al., 1999), thus bringing benefits to successive crops of cassava. Legumes and grasses are some of the plant species that contribute most to multiplication of AMFs in the soil, whereas other common cover crops, such as oilseed radish, are non-mycotrophic (Gomide et al., 2009). However, little is known about the level of interference of monocropping or intercropping of cover crops on AMFs communities; cover crops may differ in their ability to select fungi and to affect their multiplication, which can cause changes in the AMFs community (Carrenho et al., 2002).

Spores have been used for assessment of AMFs communities in different agro-ecosystems, (Souza et al., 2010), but further taxonomic knowledge is required to determine the occurrence of those fungi. Nevertheless, AMFs spore density is often unrelated to plant root formation since other propagules, such as hyphae and colonized root fragments, may lead to mycorrhization of plants. In this context, the use of molecular techniques is a tool for better evaluation of the effects of management systems on AMF populations present in the soil (Smith and Read, 2008). In addition, these techniques make it possible to characterize and provide an in-depth description of the structure and succession of microorganisms in the soil (Novais et al., 2010). One of the common molecular techniques, PCR-DGGE (polymerase chain reaction-denaturing gradient gel electrophoresis), is currently used to evaluate the profile of AMF communities from agricultural soils (Gollotte et al., 2004; Liang et al., 2008).

Since cassava is highly mycotrophic, cover crops must cause differences in AMFs community composition, besides affecting performance of the cash crop. The objective of this study was to evaluate an AMFs community, through PCR-DGGE, in cassava (Manihot esculenta Crantz) grown after cover crops, as well as determine the influence of such cultivation on mineral nutrition and yield of cassava grown in an organic system.

\section{MATERIAL AND METHODS}

The experiment was conducted in an area with an Argissolo Vermelho-Amarelo Distrófico (330 $\mathrm{g} \mathrm{kg}^{-1}$ clay) at the Experimental Station of the Empresa de Pesquisa Agropecuária e Extensão Rural de Santa Catarina - Epagri (Agricultural Research Corporation of Santa Catarina), located in the municipality of Urussanga, SC, Brazil, from $7 / 16 / 2012$ to $8 / 16 / 2013$. Over the previous seven years, the area grew various species under organic management. The organic fertilization, with respective amount of N-P-K applied, and the results of soil chemical analysis are in table 1 .

A randomized block design was used with four replications, and six treatments with different cover crops: oats $(\mathrm{O})$, vetch $(\mathrm{V})$, oilseed radish $(\mathrm{R}), \mathrm{O}+\mathrm{V}$ intercropping, and $\mathrm{O}+\mathrm{V}+\mathrm{R}$ intercropping, as well as a control treatment (fallow), which was mowed every 15 days. The plots measured $19.45 \mathrm{~m}^{2}$.

Plots with $\mathrm{O}, \mathrm{V}$, and $\mathrm{R}$ received 120, 140, and $20 \mathrm{~g}$ of seeds, respectively, and the intercropped treatments received $\mathrm{O}, \mathrm{V}$, (and $\mathrm{R}$ ) at the rate of 30,40 , (and 10) $\mathrm{g}$ of seeds, respectively. At 110 days after planting, the cover crops were mowed, and cassava stem cuttings (genotype Oriental) began to be planted. Stem cuttings of $0.15 \mathrm{~m}$ length and three to four buds were used. Spacing between rows and plants was $0.90 \mathrm{~m}$, with five rows and six stem cuttings per row.

At 110 days after cover crop planting and prior to cassava planting, soil samples were collected from the 0.00-0.10 m layer. Four subsamples were collected from each plot, for a total of 24 composite samples. The samples were used for characterization of the species and total spore counts, evaluation of the Most Probable Number (MPN) of infective propagules, and structural analysis of AMFs communities (Bagyaraj and Stürmer, 2010).

For total spore count, spores were extracted from $50 \mathrm{~mL}$ of the soil by the wet sieving technique (Gerdemann and Nicolson, 1963), followed by water and sucrose-gradient centrifugation (Jenkins, 1964). Spore density in the soil was determined by counting 
Table 1. History of the experimental area, information about previous crops, fertilization and physical-chemical analysis of the Argissolo Vermelho-Amarelo Distrófico

\begin{tabular}{|c|c|c|c|c|}
\hline Year & Crop & Natural fertilization & N-P-K applied & Chemical analysis \\
\hline \multicolumn{5}{|c|}{$\mathrm{kg} \mathrm{ha-1}$} \\
\hline \multirow[t]{3}{*}{2006} & Tomato & Chicken manure & $147-209-149$ & $22 \mathrm{~g} \mathrm{~kg}^{-1} \mathrm{OM} ; \mathrm{pH}\left(\mathrm{H}_{2} \mathrm{O}\right)$ 5.8; SMP Index 6.5; \\
\hline & Brassica & Chicken manure + aviary litter & $450-401-232$ & $28.5 \mathrm{mg} \mathrm{kg}^{-1} \mathrm{P}$ and $160 \mathrm{mg} \mathrm{kg}^{-1} \mathrm{~K}$ (both extractable by \\
\hline & & & & $\begin{array}{l}\text { Mehlich-1); } 0.0 \mathrm{cmol}_{\mathrm{c}} \mathrm{kg}^{-1} \mathrm{Al}^{3+}, 7.7 \mathrm{cmol}_{\mathrm{c}} \mathrm{kg}^{-1} \mathrm{Ca}^{2+} \text {, and } \\
1.3 \mathrm{cmol}_{\mathrm{c}} \mathrm{kg}^{-1} \mathrm{Mg}^{2+}\left(\text { both extractable by } 1 \mathrm{~mol} \mathrm{~L}^{-1} \mathrm{KCl}\right)\end{array}$ \\
\hline \multirow[t]{2}{*}{2007} & Green fertilizers $(1)$ & Chicken manure & $450-401-232$ & $\mathrm{NR}^{(2)}$ \\
\hline & Cassava & & & \\
\hline \multirow[t]{3}{*}{2008} & Tomato & $\mathrm{ND}^{(3)}$ & ND & $22 \mathrm{~g} \mathrm{~kg}^{-1} \mathrm{OM} ; \mathrm{pH}\left(\mathrm{H}_{2} \mathrm{O}\right)$ 5.9; SMP Index 6.2 \\
\hline & Maize & ND & ND & $78.3 \mathrm{mg} \mathrm{kg}^{-1} \mathrm{P}$ and $314 \mathrm{mg} \mathrm{kg}^{-1} \mathrm{~K}$ (both extractable by \\
\hline & & & & $\begin{array}{l}\text { Mehlich-1); } 0.0 \mathrm{cmol}_{\mathrm{c}} \mathrm{kg}^{-1} \mathrm{Al}^{3+}, 5.4 \mathrm{cmol}_{\mathrm{c}} \mathrm{kg}^{-1} \mathrm{Ca}^{2+} \text {, and } \\
2.5 \mathrm{cmol}_{\mathrm{c}} \mathrm{kg}^{-1} \mathrm{Mg}^{2+}\left(\text { both extractable by } 1 \mathrm{~mol} \mathrm{~L}^{-1} \mathrm{KCl}\right)\end{array}$ \\
\hline \multirow[t]{2}{*}{2009} & Tomato & Aviary litter & $398-457-238$ & NR \\
\hline & Potato & & $200-380-280$ & \\
\hline \multirow[t]{3}{*}{2010} & Tomato & Chicken manure & $396-1260-208$ & $23 \mathrm{~g} \mathrm{~kg}-1 \mathrm{OM} ; \mathrm{pH}\left(\mathrm{H}_{2} \mathrm{O}\right)$ 5.5; SMP Index 6.1; \\
\hline & Brassica & & $264-840-138$ & $17.5 \mathrm{mg} \mathrm{kg}^{-1} \mathrm{P}$ and $222 \mathrm{mg} \mathrm{kg}^{-1} \mathrm{~K}$ (both extractable by \\
\hline & & & & $\begin{array}{l}\text { Mehlich-1); } 0.0 \mathrm{cmol}_{\mathrm{c}} \mathrm{kg}^{-1} \mathrm{Al}^{3+}, 6.6 \mathrm{cmol}_{\mathrm{c}} \mathrm{kg}^{-1} \mathrm{Ca}^{2+} \text { and } \\
0.0 \mathrm{cmol}_{\mathrm{c}} \mathrm{kg}^{-1} \mathrm{Mg}^{2+} \text { (both extractable by } 1 \mathrm{~mol} \mathrm{~L}^{-1} \mathrm{KCl} \text { ) }\end{array}$ \\
\hline \multirow[t]{2}{*}{2011} & Tomato & Chicken manure & $264-840-138$ & NR \\
\hline & Potato & & $264-840-138$ & \\
\hline \multirow[t]{3}{*}{2012} & Green fertilizers & $\mathrm{IE}^{(4)}$ & IE & $17 \mathrm{~g} \mathrm{~kg}^{-1} \mathrm{OM} ; \mathrm{pH}\left(\mathrm{H}_{2} \mathrm{O}\right)$ 6.1; SMP Index 6.5; \\
\hline & Cassava & & & $147.9 \mathrm{mg} \mathrm{kg}^{-1} \mathrm{P}$ and $241.1 \mathrm{mg} \mathrm{kg}^{-1} \mathrm{~K}$ (both extractable \\
\hline & & & & $\begin{array}{l}\text { by Mehlich-1); } 0.0 \mathrm{cmol}_{\mathrm{c}} \mathrm{kg}^{-1} \mathrm{Al}^{3+}, 3.2 \mathrm{cmol}_{\mathrm{c}} \mathrm{kg}^{-1} \mathrm{Ca}^{2+} \text { and } \\
1.5 \mathrm{cmol}_{\mathrm{c}} \mathrm{kg}^{-1} \mathrm{Mg}^{2+}\left(\text { both extractable by } 1 \mathrm{~mol} \mathrm{~L}^{-1} \mathrm{KCl}\right)\end{array}$ \\
\hline
\end{tabular}

(1) Green fertilizers: intercropping - oats, ryegrass, and oilseed radish. (2) NR: Chemical analysis performed. (3) ND: not available. (4) IE: experiment set up.

the spores in a plate under a $40 \mathrm{X}$ magnification stereomicroscope (Carl Zeiss MicroImaging, Gottingen, Germany). A sample composed of 24 collected soil samples was sent to the Botany Laboratory of FURB for taxonomic identification of the AMFs species.

For evaluation of the MPN, $60 \mathrm{~mL}$ of soil samples were sieved through a $2 \mathrm{~mm}$ mesh, diluted in a $10^{1}$ to $10^{5}$ decimal series, with five replicates, and homogenized with $540 \mathrm{~mL}$ of autoclaved soil. A Rhizophagus clarus (UFSC 06) inoculum, containing 953 spores in $50 \mathrm{~mL}$ of soil, was used as a reference. The resulting mixtures were placed in $100 \mathrm{~mL}$ tubes, sown with sorghum (Sorghum bicolor) and kept in a greenhouse for 45 days (Bagyaraj and Stürmer, 2010). Afterwards, the roots were bleached (Koske and Gemma, 1989) and evaluated for the presence or absence of mycorrhizal colonization, and the MPN was determined as described by Alexander (1982).

For evaluations of root colonization and the structure of AMFs communities in the cassava roots, collections were made at 33 and 110 days after planting (DAP) of the crop. The roots were collected randomly, disregarding the plants present in the surroundings, packed in brown paper bags, and kept under refrigeration. The percentage of mycorrhizal colonization was determined by the grid-line intersect method proposed by Giovannetti and Mosse (1980), after whitening and staining the roots (Koske and Gemma, 1989).

Evaluation of the structure of AMFs communities, both for soil samples and cassava roots, was performed by the PCR-DGGE method. Total DNA extraction for the soil samples used the PowerSoil ${ }^{\circledR}$ DNA Isolation extraction kit (MOBIO Laboratories, Inc., Carlsbad, CA, USA), according to manufacturer's instructions. Prior to total DNA extraction from the root samples, the root surface was disinfected by immersion for $1 \mathrm{~min}$ in $70 \%$ ethanol, 3 min in sodium hypochlorite solution $(2.5 \%$ active chlorine) (v/v), 1 min in $70 \%$ alcohol, and two rinses for $1 \mathrm{~min}$ in sterile distilled water (Coombs and Franco, 2003). Subsequently, approximately $0.5 \mathrm{~g}$ of disinfected roots was macerated in liquid nitrogen, and DNA was extracted by the CTAB $2 \%$ method (Doyle and Doyle, 1990).

With the DNA extracted for both the soil samples and the roots, partial amplification of the $28 \mathrm{~S}$ rDNA gene was performed with specific primers for fungi: LR1 (5' GCA TAT CAA TAA GCG GAG GA3') and LR2 (5' GTC GTT TAA AGC CAT TAC GTC 3') (van Tuinen et al., 1998; Trouvelot et al., 1999). The PCR product was used in the second amplification with AMF-specific primers, FLR3 (5' TTG AAA GGG AAA CGA TTG AAG T 3') and FLR4 (5' TAC GTC AAC ATC CTT AAC GAA 3') (Gollotte et al., 2004). 
Amplification in both reactions was performed in a buffer for Taq DNA polymerase, containing $0.2 \mathrm{mmol} \mathrm{L}^{-1} \mathrm{dNTPs}, 3 \mathrm{mmol} \mathrm{L}{ }^{-1} \mathrm{MgCl}_{2}, 1 \mathrm{U}$ Taq DNA polymerase (Invitrogen, São Paulo, Brazil), $10 \mathrm{mmol} \mathrm{L}^{-1}$ of each primer, $10 \mathrm{ng}$ of extracted DNA or DNA from the product of the first PCR (Gollotte et al., 2004). PCR amplification conditions were $5 \mathrm{~min}$ at $94^{\circ} \mathrm{C}, 35$ cycles for $1 \mathrm{~min}$ at $93^{\circ} \mathrm{C}, 51 \mathrm{~min}$ at $58^{\circ} \mathrm{C}$, and $1 \mathrm{~min}$ at $72^{\circ} \mathrm{C}$, and final extension for $10 \mathrm{~min}$ at $72^{\circ} \mathrm{C}$.

Equal quantities of amplicons of the second $\mathrm{PCR}$ reaction (300 $\mathrm{ng}$ ) were analyzed by gel electrophoresis with $8 \%(\mathrm{w} / \mathrm{v})$ bisacrylamide acrylamide: (37.5:1.0, w:w) containing a gradient of 15 to $55 \%$ formamide and urea. Electrophoresis was carried out at $200 \mathrm{~V}$ and constant $60^{\circ} \mathrm{C}$ for $4.5 \mathrm{~h}$ using a "DCode" system (BioRad, Hercules, CA, USA) and 1X TAE buffer. Gels were stained with Sybr Green (Life Technologies, São Paulo, SP, Brazil) and gel images were made by Gel Logic 220 Pro Imaging System (Carestream Health, New York, USA).

Cassava plants were evaluated at 33 and 110 DAP for leaf $\mathrm{P}$ content. Four young leaves near the plant apex were collected, dried at $65{ }^{\circ} \mathrm{C}$ to constant weight, and crushed in a Willey mill with $0.5 \mathrm{~mm}$ sieves. Leaf $\mathrm{P}$ analysis was performed according to Tedesco et al. (1995).

At 33 DAP of cassava, initial plant stand was evaluated for four plants per plot, considering height and stem diameter. At the end of the experiment, at 304 DAP, cassava yield was estimated for four plants per plot. During this period, weeds present in the area were identified.

To evaluate the variables of number of spores, MPN, and mycorrhizal colonization, the data were subjected to analysis of variance, and mean values were compared by Tukey's test at $5 \%$ probability. Data on number of spores were transformed to $\log (\mathrm{x}+1)$, while MPN and mycorrhizal colonization were transformed to $\log (\mathrm{x})$ and arcsine (\% colonization/100) $)^{0.5}$, respectively.

The structure of AMFs communities was assessed with the software Gel Compar II (BioSystematica, Wales, UK), using hierarchical cluster analysis, the Jaccard coefficient, and the UPGMA clustering method. The matrix for presence-absence of amplicons, generated by the Jaccard coefficient, was used for calculation of the Venn diagram (http://bioinformatics.psb.ugent.be/webtools/Venn/).

\section{RESULTS AND DISCUSSION}

\section{Occurrence of AMF}

Cover crops produced significant effects $(p<0.01)$ on the quantity of infective propagules of AMF in the soil (Table 1). Spore density ranged from 3.8 to
$9.8 \mathrm{~mL}$ spores $\mathrm{mL}^{-1}$; the highest amount was found in the oats treatment. Similar amounts of spores are commonly found in agricultural areas after oats cultivation (Lermen et al., 2012), but they are considered to be small when compared to soils of natural ecosystems (Stürmer and Siqueira, 2011). The low occurrence of spores may be due to the no-till cropping system, which maintains the balance of the physical-chemical properties of the soil and does not stimulate spore formation. This does not occur in the conventional system, where AMFs species survival is related to the formation of resistant propagules (Carrenho et al., 2010).

The inoculum potential of AMFs as determined by the MPN method showed that intercropping with oats, vetch, and oilseed radish resulted in a six-fold increase in inoculum potential compared to the treatment with vetch only, whereas the control treatment showed intermediate inoculum potential. However, such MPN values are approximately 100 times lower than those of the R. clarus inoculum used in this study as a reference. Nevertheless, the introduction of monocropped or intercropped oats increased the number of AMFs propagules in the soil compared to the vetch treatment, showing that the monocropping or intercropping of oats increases the number of propagules of AMFs. This may be due to the fasciculate roots of this grass and also because it is recognized as a multiplier of AMFs (Gomide et al., 2009). Studies have shown that the production of spores and inoculum potential are not directly associated with plant developmental stages or any climatic or seasonal variable, and there may be situations with no relationship between sporulation and AMFs root colonization (Merryweather and Fitter, 1998).

During spore count, nine AMF species were identified, including Acaulospora mellea, $A$. morrowiae, Dentiscutata heterogama, Funnneliformis mosseae, Glomus sp1, Glomus sp2, Glomus sp3, Paraglomus ocover cropultum, and Scutellospora sp (Redecker et al., 2013). In a cassava crop area after 82 days of pre-cultivation with legumes and sorghum, Souza et al. (1999) reported the occurrence of 16 AMFs species, with the genus Glomus showing the highest frequency. In addition, the authors found that pre-cultivation of sorghum resulted in significant increases in the number of AMFs propagules in the soil, a similar behavior observed for oats (monocropped or intercropped) in the present study.

The AMFs species identified were widely found in the experimental area, without significant effects of the treatments on the number of identified morphotypes. For this reason, priority was given to assessing the effects of cover crops on AMFs communities by means of the PCR-DGGE technique.

Although there is low inoculum potential in the soil after cover crop cultivation, cassava showed 
high mycorrhizal colonization values at 33 DAP (Balota et al., 1999) (Table 2), with the highest rate occurring in the $\mathrm{O}+\mathrm{V}$ treatment. Even the mowed treatment showed mycorrhizal colonization of $70 \%$, which is considered to be high (Sieverding, 1991).

This high mycorrhizal colonization may be due to the high degree of mycotrophism of cassava in its early growth stages, since cassava has a poorly developed root system (Colozzi and Nogueira, 2007). Indeed, field studies have reported percentages of cassava mycorrhizal colonization ranging from 31 to 85 \% (Balota et al., 1999; Burns et al., 2012), which confirms the results of this study. Pre-cultivation of the cover crop had little influence on cassava mycorrhizal colonization at $110 \mathrm{DAP}$, and this may be associated with lower mycorrhizal dependency in the advanced stages of the crop in terms of $\mathrm{P}$ nutrition (Ramos and Martins, 2010), as well as root thickening, which hinders the establishment of mycorrhizal symbiosis (Zangaro and Moreira, 2010).

The occurrence of AMFs, assessed by the presence of AMFs propagules in the soil and also by cassava mycorrhizal colonization, is influenced not only by cover crop treatments but also by the history of previous crops with mycotrophic plants, such as tomatoes, green manure crops, corn, and potato (Table 1), as well as the presence of weeds commonly found in the area during fallow.

While the experiment was conducted, around 20 weed species were identified, including Cynodon dactylon sp. L. (Cynodon), Digitaria ciliaris (tropical crabgrass), Amaranthus viridis L. (Slender Amaranth), Rumex obtusifolius L. (bitter dock), Commelina erecta sp. L. (white mouth

Table 2. Number of spores and infective propagules of mycorrhizal fungi and mycorrhizal colonization of cassava after cultivation of cover crops

\begin{tabular}{|c|c|c|c|c|}
\hline \multirow{2}{*}{ Treatment } & \multicolumn{2}{|c|}{$\begin{array}{c}\text { No. of infective } \\
\text { propagules }\end{array}$} & \multicolumn{2}{|c|}{$\begin{array}{l}\text { Mycorrhizal } \\
\text { colonization }\end{array}$} \\
\hline & $\begin{array}{c}\text { AMF } \\
\text { spores }\end{array}$ & MPN & $\begin{array}{c}33 \\
\text { DAP(1) } \\
\end{array}$ & $\begin{array}{c}110 \\
\text { DAP }\end{array}$ \\
\hline & \multicolumn{2}{|c|}{$\mathrm{N}^{o} \mathrm{~mL}^{-1}$} & \multicolumn{2}{|l|}{$\%$} \\
\hline Mowing (Control) & $4.2 \mathrm{ab}$ & $1.2 \mathrm{ab}^{(2)}$ & $70 \mathrm{bA}^{(2,3)}$ & $19 \mathrm{abB}$ \\
\hline Oats $(\mathrm{O})$ & $9.9 \mathrm{a}$ & $2.1 \mathrm{ab}$ & $76 \mathrm{abA}$ & $20 \mathrm{aB}$ \\
\hline Vetch (V) & $4.9 \mathrm{ab}$ & $0.6 \mathrm{~b}$ & $71 \mathrm{bA}$ & $19 \mathrm{abB}$ \\
\hline Oilseed radish (R) & $5.2 \mathrm{ab}$ & $1.1 \mathrm{ab}$ & $68 \mathrm{bA}$ & $13 \mathrm{bB}$ \\
\hline $\mathrm{O}+\mathrm{V}$ & $6.6 \mathrm{ab}$ & $2.3 \mathrm{ab}$ & $82 \mathrm{aA}$ & $16 \mathrm{abB}$ \\
\hline $\mathrm{O}+\mathrm{V}+\mathrm{R}$ & $3.8 \mathrm{~b}$ & $3.9 \mathrm{a}$ & $70 \mathrm{bA}$ & $20 \mathrm{aB}$ \\
\hline $\begin{array}{l}\text { Rhizophagus } \\
\text { clarus (reference) }\end{array}$ & 19 & 183 & - & - \\
\hline CV (\%) & 7.55 & 2.50 & 4.88 & \\
\hline
\end{tabular}

(1) Days after planting. (2) Means followed by the same lowercase letter among treatments vertically, and (3) means followed by the same capital letter among sampling times horizontally do not differ by the Tukey test at $5 \%$. dayflower), Veronica persica Poir. (bird's-eye), Cyperus rotundus sp. L. (nut grass), Amaranthus deflexus L. (perennial pigweed), Stellaria media (L.) Vill (chickweed), Sida spinosa L. (prickly fanpetals), Silene gallica L. (catchfly), Lupinus albus (white lupin), Impomoe anil (L.) Roth (Japanese morning glory), Brachiaria plantaginea (Link) Hitchc (Alexander grass), Plantago tomentosa Lam. (plantain), Phenax sonneratti (Poir.) Wedd. (Breaks stone), Oxalis corymbosa DC. (violet wood-sorrel), Bidens sp. (beggar-ticks), Ageratum conyzoides L. (goatweed), and Ipomoea batatas Poir. (sweet potato), identified according to Lorenzi (2008). Most of these species belong to plant families with the ability to form mycorrhizal association (Purin et al., 2006). Therefore, they have the ability to form an AMF propagule bank that can affect crops grown in succession.

\section{Structure of AMF communities}

There was no similarity between treatments regarding the structure of $\mathrm{AMF}$ s communities in the soil, showing the heterogeneous distribution of these fungi and the lack of effect of monocropping or intercropping (Figure 1). The experimental area has a history of use of an organic farming system with the cultivation of various crops (Table 1), and this has a marked effect on the spread of AMF propagules in the area, thus making the structure of these fungal communities heterogeneous. Maybe only one cover crop cycle was not enough to cause notable selectivity of the AMF in the soil. The organic farming system promotes soil cover, incorporation of crop residues, use of organic fertilizers, and crop rotation. Moreover, the practice of organic farming allows better soil fertility conditions, increases organic matter content, improves infiltration of water and aeration, and promotes thermal equilibrium and the formation and stabilization of aggregates (Purin et al., 2006). This scenario may explain the low inoculum potential of AMFs in the soil (Table 2), because the formed aggregates protect, to some extent, the propagules of these fungi, reducing their capacity to associate with the cover crop. However, these propagules are still present in the soil and are eventually identified by PCR-DGGE techniques (Berbara et al., 2006).

The structure of AMFs communities in cassava roots was analyzed at 33 and $110 \mathrm{DAP}$. The dendrogram shows that there was $100 \%$ similarity between the intercropping treatments $\mathrm{O}+\mathrm{V}$ and $\mathrm{O}+\mathrm{V}+\mathrm{R}$ after 33 DAP (Figure 2a). At 110 DAP, oilseed radish with pre-cultivation was also similar to the intercropping treatments, while the control (mowing) showed low similarity to the other cover crops in both evaluation periods. These results indicate that the profiles of AMFs communities found in the cassava roots are influenced by the cover crops and by the plant developmental stage and the fungal communities are influenced by 
Coefficient of Similarity

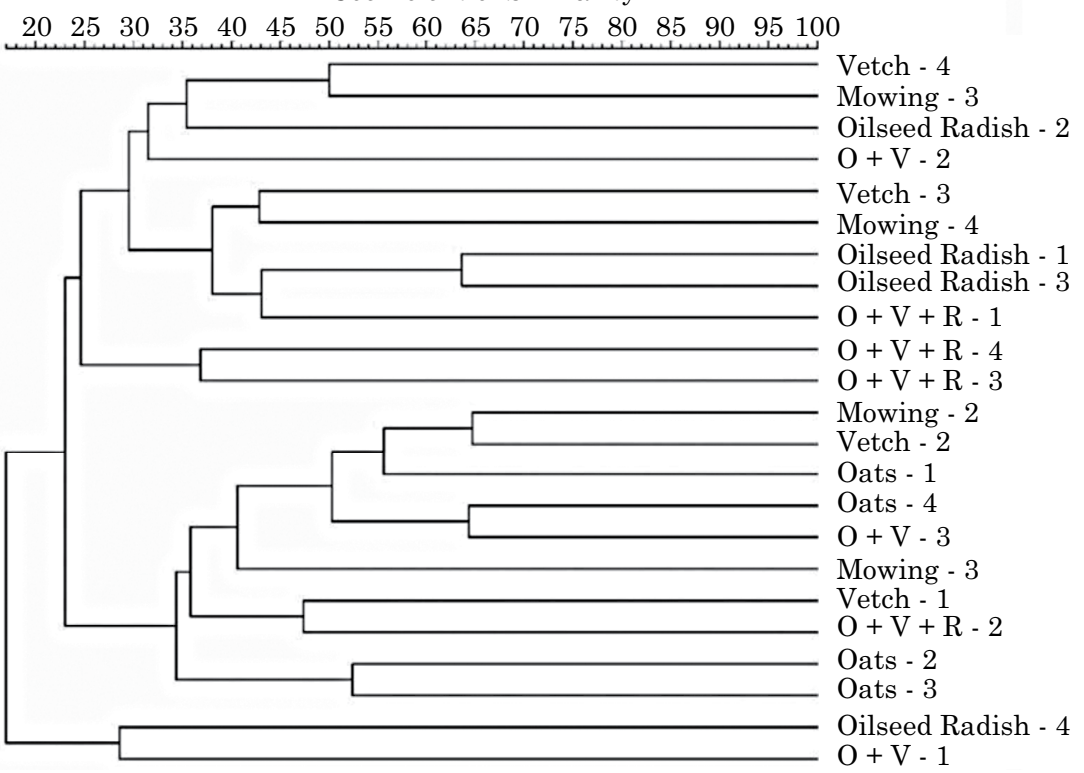

Figure 1. Dendrogram generated from PCR-DGGE of 24 soil samples, collected at 110 days after planting the cover crops. Hierarchical clustering obtained from the Jaccard coefficient and the UPGMA clustering method. The nomenclature for samples refers to the cover crop treatments, and the numbers correspond to the replications.

the plant developmental stage as well. Samples of roots in pasture areas were evaluated and Vandenkoornhuyse et al. (2003) found temporal changes in the AMFs communities. Therefore, long-term management changes, such as use of fertilizers (Lumini et al., 2010; Lin et al., 2012), may affect the permanence and, consequently, the diversity of AMFs in the soil.

The control treatment (mowing) had fewer amplicons compared to the treatment with single plants at 33 and 110 DAP (Figure 2b). Moreover, fragment distribution was modified along the cassava cycle, and the treatment with oilseed radish showed AMFs specific communities at 33 DAP. However, the AMFs communities were similar among the intercropped and the oilseed radish treatments, with common amplicons among them. Therefore, changes in the succession of fungal communities in cassava roots are evident, and this may be related to the mycorrhizal symbiosis dynamics throughout this crop cycle. As mentioned earlier, in the later stages of plant development, the dependence on AMFs may be reduced by restricting the continuity of certain groups of fungi in the roots. Glomeraceae species show intraradicular hyphae that differentiate into rich lipid globular structures called vesicles (Smith and Read, 2008), which could allow these fungi to survive in the roots, even when there is a limitation in the supply of assimilates by the symbiotic plant. The PCR-DGGE technique reveals its limitation in the impossibility of specific identification of AMF (Øvreås et al., 1997); however, the occurrence of various Glomus species in the soil may indicate that this fungal group has the potential to colonize cassava roots even in advanced crop stages. Therefore, future studies employing the sequencing technique (Lumini et al., 2010; Lin et al., 2012) could be used to identify AMF species in symbiotic succession with cassava roots throughout that crop cycle.

\section{Plant population, $P$ leaf content and yield of cassava}

Cassava growth, $\mathrm{P}$ nutrition, and yield were not affected by cover crop treatments. At 33 DAP, mean values for plant height and diameter were 12 and $0.4 \mathrm{~cm}$, respectively. Mean leaf $\mathrm{P}$ content ranged from 5.2 to $6.4 \mathrm{~g} \mathrm{~kg}^{-1}$ during cassava cultivation, regardless of the cover crop treatment used. Leaf $\mathrm{P}$ contents ranging from 2 to $5 \mathrm{~g} \mathrm{~kg}^{-1}$ are suitable for cassava crops (Howeler, 1987; CQFS-RS/SC, 2004) and, therefore, the values found in this study, regardless of the collection period, are higher than the values recommended in the literature. This can be associated with the high soil fertility (Table 1). At the end of the experiment at 304 DAP, cassava had an average estimated yield of $21 \mathrm{Mg} \mathrm{ha}^{-1}$ and no significant effect from cover crops. This yield is higher than the average yield of the cultivar Oriental in municipalities of the State of Santa Catarina, which is $15.4 \mathrm{Mg} \mathrm{ha}^{-1}$ (Epagri, 2014). Therefore, soil fertility associated with high mycorrhizal colonization of cassava in the early stages of development (Table 2) contributed to $\mathrm{P}$ nutrition and yield for this crop. 
Alves AAC. Fisiologia da mandioca. In: Souza LS, Farias ARN, Mattos PLP, Fukuda WMG, editores. Aspectos socioeconômicos e agronômicos da mandioca. Cruz das Almas: Embrapa Mandioca e Fruticultura Tropical; 2006. p.138-69.

Alves MC, Moreira MAB, Chagas MCM, Holanda JS, Silva J, Lima JDS. Recomendações técnicas para o cultivo da mandioca. In: Lira MA, Chagas MCM, Lima JMP, Holanda JS, editores. Culturas alimentares na agricultura familiar. Natal: Emparn; 2009.

Bagyaraj JD, Stürmer SL. Fungos micorrízicos arbusculares (FMAs). In: Moreira FMS, Huising EJ, Bignell DE, editores. Manual de biologia dos solos tropicais: amostragem e caracterização da biodiversidade. Lavras: Universidade Federal de Lavras; 2010. p.205-21.

Balota EL, Lopes ES, Hungria M, Döbereiner J. Ocorrência de bactérias diazotróficas e fungos micorrízicos arbusculares na cultura da mandioca. Pesq Agropec Bras. 1999;34:1265-76.

Berbara RLL, Souza FA, Fonseca HMAC. Fungos micorrízicos arbusculares: muito além da nutrição. In: Fernandes MS, editor. Nutrição mineral de plantas. Viçosa, MG: Sociedade Brasileira de Ciência do Solo; 2006. p.53-88.

Bettiol W, Ghini R, Galvão JAH, Ligo MAV, Mineiro JLC. Soil organisms in organic and conventional cropping systems. Sci Agric. 2002;59:565-72.

Burns AE, Gleadow RM, Zacarias AM, Cuambe CE, Miller RE, Cavagnaro TR. Variations in the chemical composition of cassava (Manihot esculenta Crantz) leaves and roots as affected by genotypic and environmental variation. J Agric Food Chem. 2012;60:4946-56.

Carrenho R, Gomes-da-Costa SM, Balota EL, Colozzi Filho, A. Fungos micorrízicos arbusculares em agrossistemas brasileiros. In: Siqueira JO, Souza FA, Cardoso EJBN, Tsai SM, editores. Micorrizas: 30 anos de pesquisas no Brasil. Lavras: Universidade Federal de Lavras; 2010. p.215-50.

Carrenho R, Trufem SFB, Bononi VLR. Effects of using different host plants on the detected biodiversity of arbuscular mycorrhizal fungi from an agroecosystem. R Bras Bot. 2002;25:93-101.

Carvalho PCL, Fukuda WMG. Estrutura da planta e morfologia. In: Souza LD, Farias ARN, Mattos PLP, Fukuda WMG, editores. Aspectos socioeconômicos e agronômicos da mandioca. Cruz das Almas, BA: Embrapa Mandioca e Fruticultura Tropical; 2006. p.560-90.

Colozzi A, Nogueira MA. Micorrizas arbusculares em plantas tropicais: café, mandioca e cana-de-açúcar. In: Silveira APD, Freitas SS, editores. Microbiota do solo e qualidade ambiental. Campinas: Instituto Agronômico; 2007. p.38-56.

Coombs JT, Franco CMM. Isolation and identification of actinobacteria from surface-sterilized wheat roots. Appl Environ Microbiol. 2003;69:5603-8.

Doyle JJ, Doyle JL. Isolation of DNA from small amounts of plant tissue. Focus. 1990;12:13-5.

Empresa de Pesquisa Agropecuária e Extensão Rural de Santa Catarina - Epagri. Relatório de Avaliação de cultivares de aipim, nos municípios de SC - 2013/2014. [Accessed on: 23 Feb. 2014]. Available at: http://www.epagri.sc.gov.br/.

Gerdemann JW, Nicolson TH. Spores of mycorrhizal Endogon species extracted from soil by wet-sieving decanting. Trans Brit Mycol Soc. 1963;46:235-44.

Giovannetti M, Mosse B. An evaluation of techniques for measuring vesicular-arbuscular mycorrhizal infection in roots. New Phytol. 1980;84:489-500.
Gollotte A, van Tuinen D, Atkinson D. Diversity of arbuscular mycorrhizal fungi colonizing roots of the grass species Agrostis capillaris and Lolium perenne in a field experiment. Mycorrhiza. 2004;14:111-7.

Gomide PHO, Santos JGD, Siqueira JO, Soares CRFS. Diversidade e função de fungos micorrízicos arbusculares em sucessão de espécies hospedeiras. Pesq Agropec Bras. 2009;44:1483-90.

Howeler R. Desórdenes nutricionales de la planta de yuca. Cali, Colômbia: Centro Internacional de Agricultura Tropical; 1987.

Instituto Brasileiro de Geografia e Estatística - IBGE. Produção agrícola municipal. Rio de Janeiro: 2010.

Jenkins WR. A rapid centrifugal flotation technique for separating nematodes from soil. Plant Dis Rep. 1964;48:692.

Karasawa T, Takebe M. Temporal or spatial arrangements of cover crops to promote arbuscular mycorrhizal colonization and $\mathrm{P}$ uptake of upland crops grown after nonmycorrhizal crops. Plant Soil. 2012;353:355-66.

Koske RE, Gemma JN. A modified procedure for staining roots to detect VA mycorrhizas. Mycol Res. 1989;92:486-8.

Lermen C, Ferreira FG, Camilotti J, Raimundo KF, Urcoviche RC, Guellis C, Alberton O. Potencial de inóculo de fungos micorrízicos arbusculares em solo cultivado com aveia em Umuarama - PR. Arq Ci Vet Zool Unipar. 2012;15:49-55.

Liang Z, Drijber RA, Lee DJ, Dwiekat IM, Harris SD. A DGGE-cloning method to characterize arbuscular mycorrhizal community structure in soil. Soil Biol Biochem. 2008;40:956-66.

Lin X, Feng Y, Zhang H, Chen R, Wang J, Zhang J, Chu H. Long-term balanced fertilization decreases arbuscular mycorrhizal fungal diversity in an arable soil in North China revealed by 454 pyrosequencing. Environ Sci Technol. 2012;46:5764-71.

Lorenzi H. Plantas daninhas do Brasil: terrestres, aquáticas, parasitas e tóxicas. $4^{\mathrm{a}}$.ed. Nova Odessa, SP: Instituto Plantarum de Estudos da Flora; 2008.

Lumini E, Orgiazzi A, Borriello R, Bonfante P, Bianciotto V. Disclosing arbuscular mycorrhizal fungal biodiversity in soil through a land-use gradient using a pyrosequencing approach. Environ Microbiol. 2010;12:2165-79.

Merryweather J, Fitter A. The arbuscular mycorrhizal fungi of Hyacinthoides non-scripta. II. Seasonal and spatial patterns of fungal populations. New Phytol. 1998;138:131-42.

Moreira FMS, Siqueira JO. Microbiologia e bioquímica do solo. Lavras: Universidade Federal de Lavras; 2006.

Novais CB, Souza FA, Siqueira JO. Caracterização fenotípica e molecular de esporos de fungos micorrízicos arbusculares mantidos em banco de germoplasma. Pesq Agropec Bras. 2010;45:886-96.

Øvreås L, Forney L, Daae FL, Torsvik V. Distribution of bacterioplankton in meromictic Lake Saelenvannet, as determined by denaturing gradient gel electrophoresis of PCR-amplified gene fragments coding for 16S rRNA. Appl Environ Microbiol. 1997;63:3367-73.

Purin S, Klauberg Filho O, Sturmer SL. Mycorrhizae actvity and diversity in conventional and organic apple orchards from Brazil. Soil Biol Biochem. 2006;38:1831-9.

Ramos AC, Martins MA. Fisiologia de micorrizas arbusculares. In: Siqueira JO, Souza FA, Cardoso EJBN, Tsai SM, editores. 
Micorrizas: 30 anos de pesquisas no Brasil. Lavras: Universidade Federal de Lavras; 2010. p.133-52.

Redecker D, Schüßler A, Stockinger H, Stürmer S, Morton J, Walker C. An evidence-based consensus for the classification of arbuscular mycorrhizal fungi (Glomeromycota). Mycorrhiza. 2013;23:515-31.

Sieverding E. Vesicular-arbuscularmycorrhiza management in tropical agrosystems. Eschborn: GTZ; 1991.

Smith SE, Read DJ. Mycorrhizal symbiosis. London: Academic Press; 2008.

Comissão de Química e Fertilidade do Solo - CQFS-RS/SC. Recomendações de adubação e de calagem para os Estados do Rio Grande do Sul e de Santa Catarina. $10^{\mathrm{a}}$.ed. Porto Alegre: Sociedade Brasileira de Ciência do Solo/Núcleo Regional Sul; 2004.

Souza AD, Trufem SFB, Almeida DL, Silva EMR, Guerra JGM. Efeito de pré-cultivos sobre o potencial de inóculo de fungos micorrízicos arbusculares e produção da mandioca. Pesq Agropec Bras. 1999;34:1913-23.

Souza FA, Stürmer SL, Carrenho R, Trufem SFA. Classificação e taxonomia de fungos micorrízicos arbusculares e sua diversidade e ocorrência no Brasil. In: Siqueira JO, Souza FA, Cardoso EJBN, Tsai SM, editores. Micorrizas: 30 anos de pesquisas no Brasil. Lavras: Universidade Federal de Lavras; 2010. p.15-73.

Souza LS, Souza LD. Manejo e conservação do solo. In: Souza LD, Farias ARN, Mattos PLP, Fukuda WMG, editores. Aspectos socioeconômicos e agronômicos da mandioca. Cruz das Almas, BA: Embrapa Mandioca e Fruticultura Tropical; 2006. p.540-60.

Stürmer SL, Siqueira JO. Species richness and spore abundance of arbuscular mycorrhizal fungi across distinct land uses in western Brazilian Amazon. Mycorrhiza. 2011;21:255-67.

Tedesco MJ, Gianello C, Bissani CA, Bohnen H, Volkweiss SJ. Análise de solo, plantas e outros materiais. $2^{a}$.ed. Porto Alegre: Universidade Federal do Rio Grande do Sul; 1995. (Boletim técnico, 5).

Trouvelot S, van Tuinen D, Hijri M, Gianinazzi-Pearson V. Visualization of ribosomal DNA loci in spore interphasic nucleic of glomalean fungi by fluorescence in situ hybridization. Mycorrhiza. 1999;8:203-6.

van Tuinen D, Jacquot E, Zhao B, Gollotte A, Gianinazzi-Pearson V. Characterization of root colonization profiles by a microcosm community of arbuscular mycorrhizal fungi using $25 \mathrm{~S}$ rDNA-targeted nested PCR. Molec Ecol. 1998;7:879-87.

Vandenkoornhuyse P, Ridgway KP, Watson IJ, Fitter AH, Young JP. Co-existing grass species have distinctive arbuscular mycorrhizal communities. Molec Ecol. 2003;12:3085-95.

Zangaro W, Moreira M. Micorrizas arbusculares nos biomas Floresta Atlântica e Floresta de Araucária. In: Siqueira JO, Souza FA, Cardoso EJBN, Tsai SM, editores. Micorrizas: 30 anos de pesquisas no Brasil. Lavras: Universidade Federal de Lavras; 2010. p.279-310. 